\title{
TRITERPENES AND FLAVONOIDS FROM FAGONIA MOLLIS DEL VAR. GRANDIFLORA
}

\author{
Ahmed A. Attia, and Samia A. Youssef
}

Department of Pharmacognosy, Faculty of Pharmacy, Assiut University, Assiut, Egypt

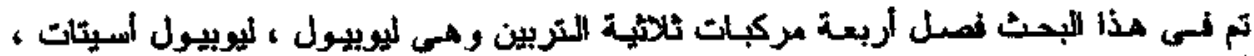

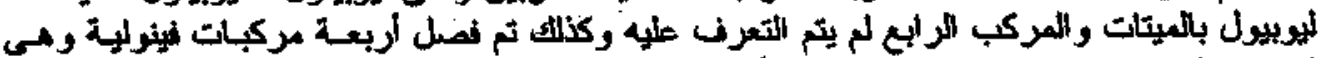

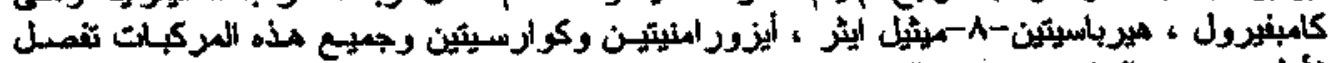

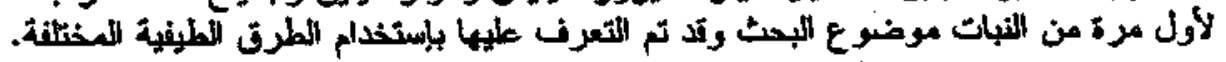

The aerial parts of the Fagonia mollis var. grandiflora afforded lupeol, lupeol acetate, lipeol palmitale and unidentified triterpene together with four flawonoids kampferol, herbacetin-8-methyl ether, isorhamnetin and quercetin. Triserpenes were identified by ${ }^{\prime} H-N M R$, ${ }^{13} \mathrm{C}-N M R$ and mass spectral analysis and flawoloids by U.V., ${ }^{t} H-N M R$ and mass spectral anatysis.

\section{INTRODUCTION}

The genus Fagonia (Family Zygophyllaceae) is represented in Egypt by 18 species, ${ }^{1}$ among which is Fagonia mollis var. grandiflora. In traditional medicine, extracts of Fagonia species were reported to exhibit medicinal properties and used for treatment of cholera, prolonged fever and snake bites. ${ }^{2,3}$ Also, it was reported that a mixture of saponins obtained from the $60 \%$ aqueous ethanolic extract of Fagonia mollis complex exhibited antiinflammatory and antipyretic activities, but a weak analgesic effect."

A literature survey revealed that this genus is rich in flavonoids and saponins..$^{5.10}$ However nothing have been reported on the isolation of the active constituents of the plant under investigation. It is the aim of this study to investigate flavonoids and triterpenes in this plant.

\section{EXPERIMENTAL}

\section{Plant material}

The plant was collected from Sinai desert near El-Arish. It was identified and authenticated by Prof. Dr. A. Fayed, Professor of Plant
Taxonomy, Dept. of Botany, Faculty of Science, Assiut University. The aerial parts were airdried, powdered and kept in well closed dark container till used.

\section{General procedures}

Melting points were uncorrected and determined with Koffler hot stage microscope. UV spectra were recorded using Unicam 1750 spectrophotometer with Pye-Unicam Ar' 55 linear recorder. Varian $J M_{3} \mathbf{N G X 5 0 0}$ spectrometer $\left(500 \mathrm{MHz}\right.$ for ${ }^{1} \mathrm{H}-\mathrm{NMR}$ and 125 $\mathrm{MHz}$ for ${ }^{13} \mathrm{C}-\mathrm{NMR}$ ) in $\mathrm{CDCl}_{3}, \mathrm{DMSO}_{\mathrm{6}}$ and JEOL JMS-DX $300 \mathrm{~L}$ Mass spectrometer for MS measurements. Silica gel (E. Merck) was used for column chromatography for separation of triterpenes. Silica gel G60 was used for monitoring of triterpenes using hexane-ethyl acetate $(85: 15 \mathrm{v} / \mathrm{v})$ as solvent system, while Whatman No. 3. paper chromatography was used for separation of flavonoids using system: n-butanol-acetic acid-water [BAW (4:1:2 v/v)].

Isolation and characterization of compounds

The powdered air-dried aerial parts $(2 \mathrm{Kg})$ were extracted with methanol till exhaustion. The extract was concentrated under reduced pressure to syrupy consistency, mixed with

Raceived in $3 / 11 / 1998$ Accepted in 10/4/1999 
water and successively extracted with hexane and chloroform. Both hexane and chloroform fractions were subjected to chromatographic examination for their contents.

The hexane fraction $(10 \mathrm{~g})$ was subjected to column chromatography using hexane-EtOAc gradient, where compound 1 was eluted with hexane-ethyl acetate $(95: 5)$, further fractions using the same polarity gave compound 2 , while further elution using hexane-EtOAc $(94: 6)$ gave compound 3, elution with hexane-EtOAc (92:8) gave compound 4.

The chloroform fraction $(8 \mathrm{~g})$ was subjected to column chromatography on silica gel using chloroform-methanol gradient. The similar fractions were collected and subjected to paper chromatography using "n-butanol-acetic acidwater $(4: 1: 2)$ and $15 \%$ acetic acid as solvent systems. Preparative paper chromatography was used to separate the components, where four compounds were isolated F1-F4.

Compound 1: needles from acetone, m.p. 210$212^{\circ} \mathrm{C}$. EIMS, $\mathrm{m} / \mathrm{z} 426$, other fragments: 407 , 411, 218, 207 and 204. 'H-NMR: $\delta 3.19(1 \mathrm{H}$, dd, $\mathrm{J}=5.0,11.0 \mathrm{~Hz}, \mathrm{H}-3), 2.38(1 \mathrm{H}$, ddd, $\mathrm{J}=$ $5.95,11.0,11.0 \mathrm{~Hz}, \mathrm{H}-19), 0.93(3 \mathrm{H}, \mathrm{s}, \mathrm{H}-23)$, $0.75(3 \mathrm{H}, \mathrm{s}, \mathrm{H}-24), 0.82(3 \mathrm{H}, \mathrm{s}, \mathrm{H}-25), 1.03$ $(3 \mathrm{H}, \mathrm{s}, \mathrm{H}-26), 0.96(3 \mathrm{H}, \mathrm{s}, \mathrm{H}-27), 0.78(3 \mathrm{H}, \mathrm{s}$, H-28), 4:56 (1H, s, H-30), $4.68(1 \mathrm{H}, \mathrm{s}, \mathrm{H}-30)$, $1.68(3 \mathrm{H}, \mathrm{s}, \mathrm{H}-29) .{ }^{13} \mathrm{C}-\mathrm{NMR}$ (Table 1).

Compound 2: needles from methanol, m.p. $215-218^{\circ} \mathrm{C}$. EIMS, $\mathrm{m} / \mathrm{z} 468$, other fragments: 453, 249, 218, 209, 203 and 189. 'H-NMR: $\delta 4.50(1 \mathrm{H}$, dd, J $=8.4,4.80 \mathrm{~Hz}, \mathrm{H}-3), 2.38$ (1H, ddd, J $=5.98,11.07,11.07 \mathrm{~Hz}, \mathrm{H}-19$ ), $0.81(3 \mathrm{H}, \mathrm{s}, \mathrm{H}-23), 0.82(3 \mathrm{H}, \mathrm{s}, \mathrm{H}-24), 0.83$ $(3 \mathrm{H}, \mathrm{s}, \mathrm{H}-25), 1.04(3 \mathrm{H}, \mathrm{s}, \mathrm{H}-26), 0.95(3 \mathrm{H} ; \mathrm{s}$, H-27), 0.78 (3H, s, H-28), 1.66 (3H, s, H-29), 4.58 (1H, br.s, H-30), 4.69 (1H; br.s, H-30) and $2.1\left(3 \mathrm{H}, \mathrm{s}, \mathrm{COCH}_{\mathrm{H}}\right) .{ }^{13} \mathrm{C}$-NMR (Table 1).

Compound 3: Amorphous powder, m.p. 230$232^{\circ} \mathrm{C}$ (from methanol). EIMS $\mathrm{m} / \mathrm{z}$ : 664 , fragments, $649,621,425,408,218$ and 189 . ${ }^{1} \mathrm{H}-\mathrm{NMR}: \delta 0.88\left(3 \mathrm{H}, \mathrm{t}, \mathrm{J}=6.9 \mathrm{~Hz}, \mathrm{CH}_{3}\right.$ terminal of fatty acid), $1.28\left(\mathrm{~m}, \mathrm{CH}_{2}\right.$-residue of fatty acid), other protons as in lupeol. ${ }^{13} \mathrm{C}$-NMR (Table 1).

Compound 4: Was obtained as amorphous powder, m.p. $227-229^{\circ} \mathrm{C}$ (from methanol). EIMS $\mathrm{m} / \mathrm{z}: 482$, other fragments, 453 . (M$\mathrm{CHO}), 298,263,249,218,189,175$ and 161. 'H-NMR: $\delta 9.00$ (1H, s, CHO), other signals similar to lupeol acetate. ${ }^{13} \mathrm{C}-\mathrm{NMR}$ (Table 1).

Compound F1: Yellow needle (MeOH), m.p. 282-284 ${ }^{\circ} \mathrm{C}$. EIMS m/z: (rel. int.\%) $286(60)$, 258 (48), 153 (3) and 152 (5), 'H-NMR (Table 2) and U.V. (Table 3).

Compound F2: Yellow amorphous powder $(\mathrm{MeOH})$, m.p. $269-271^{\circ} \mathrm{C}$. EIMS m/z: (rel. int. \%) 316 (100), 315 (55), 301 (11), 167 (8), 121 (13) and 93 (3). U.V. (Table 3).

Compound F3: Yellow amorphous powder, m.p. $308-310^{\circ} \mathrm{C}$. EIMS m/z: (rel. int.\%) 316 (25), 301 (5), 230 (6), 149 (15) and 121 (8). ${ }^{1} \mathrm{H}-$ NMR (Table 2) and U.V. (Table 3).

Compound F4: Yellow needle (MeOH), m.p. $314-316^{\circ} \mathrm{C}$. EIMS $\mathrm{m} / \mathrm{z}$ : (rel. int.\%) 302 (100), $286(70), 274(20), 152(5), 137(30)$ and 122 (15). 'H-NMR (Table 2) and U.V. (Table 3).

\section{RESULTS AND DISCUSSION}

From the aerial parts of Fagonia mollis V. grandiflora four triterpenes 1-4 were isolated from the hexane fraction, while four flavonoid aglycones were isolated from the chloroform fraction. The identification of these compounds was based on the study of physical, chemical, chromatographic as well as the spectroscopic data (UV, 'H-NMR, ${ }^{13} \mathrm{C}-\mathrm{NMR}$ and Mass spectra).

Compound 1: was chromatographically non identical with authentic samples of $\alpha$ and/or Bamyrin. In the Mass spectrum, the molecular ion was detected at $\mathrm{m} / \mathrm{z} 426$ and other fragments at $\mathrm{m} / \mathrm{z} 218$ and $\mathrm{m} / \mathrm{z} 207$ which were derived from a Retro-Diels-Alder fragmentation for a 
Table 1: The ${ }^{13} \mathrm{C}-\mathrm{NMR}$ chemical shifts of compounds 1-4 $\left(\mathrm{CDCl}_{3}\right)$,

\begin{tabular}{|c|c|c|c|c|c|c|c|c|c|}
\hline & 1 & 2 & 3 & 4 & & $\mathbf{1}$ & 2 & 3 & 4 \\
\hline C-1 & 38.7 & 38.7 & 38.7 & 38.9 & C-20 & 150.9 & 150.9 & 151.2 & 151.2 \\
\hline $\mathrm{C}-2$ & 23.8 & 27.4 & 25.0 & 27.4 & $\mathrm{C}-21$ & 29.8 . & 29.8 & 30.0 & 30.0 \\
\hline C-3 & 81.2 & 78.9 & 81.2 & 78.9 & C-22 & 40.0 & 40.0 & 40.2 & 40.2 \\
\hline$C-4$ & 38.8 & 38.8 & 39.0 & 55.9 & C-23 & 28.0 & 28.0 & 28.2 & 22.1 \\
\hline C-5 & 55.3 & 55.3 & 55.5 & 48.0 & C-24 & 15.4 & 15.4 & 15.6 & 200.1 \\
\hline C-6 & 18.2 & 18.3 & 18.5 & 21.0 & C-25 & 16.1 & 16.1 & 16.3 & 16.3 \\
\hline C-7 & 34.2 & 34.2 & 34.7 & 34.7 & C-26 & 15.9 & 15.9 & 16.2 & 16.2 \\
\hline $\mathrm{C}-8$ & 40.8 & 40.8 & 41.0 & 41.0 & $\mathrm{C}-27$ & 14.5 & 14.5 & 14.7 & 14.7 \\
\hline C-9 & 50.4 & 50.4 & 50.6 & 50.6 & C-28 & 18.0 & 18.0 & 18.2 & 18.2 \\
\hline C-10 & 37.2 & 37.1 & 37.2 & 37.2 & C-29 & 19.3 & 19.3 & 19.5 & 19.5 \\
\hline C-11 & 20.9 & 20.9 & 21.1 & 21.1 & C-30 & 109.3 & 109.3 & 109.5 & 109.5 \\
\hline C-12 & 25.1 & 25.1 & 25.3 & 25.3 & Ac & 21.3 & & & 21.3 \\
\hline C-13 & 38.0 & 38.0 & 38.3 & 38.3 & & 173.6 & & $\ldots$ & 173.6 \\
\hline C-14 & 42.8 & 42.8 & 43.2 & 43.2 & F.A. & & & & $\vdots$ \\
\hline C-15 & 27.4 & 27.4 & 27.6 & 27.6 & $\mathrm{CH}_{3}-\mathrm{T}$ & & & 14.3 & \\
\hline C-16 & 35.5 & 35.5 & 35.8 & 35.6 & $\mathrm{CH}_{2}-\mathrm{CH}_{3}$ & & & 22.4 & \\
\hline C-17 & 43.0 & 43.0 & 43.0 & 42.8 & $\mathrm{CH}_{2}-\mathrm{C}=\mathrm{O}$ & & & 34.1 & \\
\hline C-18 & 48.2 & 48.2 & 48.5 & 48.3 & $\mathrm{CH}_{2} \mathrm{CH}_{2} \mathrm{C}=\mathrm{O}$ & & & 24.6 & \\
\hline C-19 & 47.9 & 47.9 & 48.2 & 48.2 & $\mathrm{CH}_{2}-\mathrm{C}=\mathrm{O}$ & & & $\begin{array}{c}32.1 \\
29.5- \\
29.9 \\
174.6\end{array}$ & \\
\hline
\end{tabular}

F.A. = Fatty acid; Ac = Acetate; T. $=$ Terminal

Table 2: 'H-NMR data of the flavonol, F1 ( $\left.\mathrm{CDCL}_{3}\right), \mathrm{F} 3$ and F4 (DMSO-d $\left.\mathrm{d}_{6}\right)$

\begin{tabular}{|c|c|c|c|c|c|c|c|}
\hline Compound & H-2, & H-6, & H-3 & H-5 & H-6 & H-8 & Ome \\
\hline \multirow{2}{*}{ F1 } & $\begin{array}{r}8.2, \mathrm{~d}, \\
\mathrm{~J}=2.5\end{array}$ & $\begin{array}{c}8.2, \mathrm{~d}, \\
\mathrm{~J}=2.5\end{array}$ & $\begin{array}{c}6.95, \mathrm{~d}, \\
\mathrm{~J}=2.5\end{array}$ & $\begin{array}{c}6.95, \mathrm{~d}, \\
\mathrm{~J}=2.5\end{array}$ & $\begin{array}{c}6.54, \mathrm{~d}, \\
\mathrm{~J}=2.5\end{array}$ & $\begin{array}{c}6.30, \mathrm{~d}, \\
\mathrm{~J}=2.5\end{array}$ & - \\
\hline \multirow{2}{*}{$\mathrm{F3}$} & $\begin{array}{c}7.6, \mathrm{~d}, \\
\mathrm{~J}=2.5\end{array}$ & $\begin{array}{c}7.5, \mathrm{~d}, \\
\mathrm{~J}=2.5\end{array}$ & & $\begin{array}{c}6.95, \mathrm{~d}, \\
\mathrm{~J}=9.0\end{array}$ & $\begin{array}{c}6.44, \mathrm{~d}, \\
\mathrm{~J}=2.5\end{array}$ & $\begin{array}{c}6.22, \mathrm{~d}, \\
\mathrm{~J}=2.2\end{array}$ & $3.62, \mathrm{~s}$ \\
\hline \multirow{2}{*}{$\mathrm{F} 4$} & $\begin{array}{c}7.66, \mathrm{~d}, \\
\mathrm{~J}=2.0\end{array}$ & $\begin{array}{c}7.54, \mathrm{~d}, \\
\mathrm{~J}=2.8\end{array}$ & - & $\begin{array}{c}6.97, \mathrm{~d}, \\
\mathrm{~J}=2.5\end{array}$ & $\begin{array}{c}6.41, \mathrm{~d}, \\
\mathrm{~J}=2.5\end{array}$ & $\begin{array}{c}7.19, \mathrm{~d}, \\
\mathrm{~J}=2.0\end{array}$ & - \\
\hline
\end{tabular}


Table 3: UV spectral data of the isolated compounds F1-F4.

\begin{tabular}{|c|c|c|c|c|c|c|c|c|}
\hline \multicolumn{2}{|c|}{$\begin{array}{l}\text { Comp. } \\
\text { Reagent }\end{array}$} & $\mathrm{MeOH}$ & $+\mathrm{AlCl}_{3}$ & $\begin{array}{l}+\mathrm{AlCl}_{3} \\
+\mathrm{HCl}\end{array}$ & $+\mathrm{NaOAc}$ & $\begin{array}{l}+\mathrm{NaOAc} \\
+\mathrm{H}_{3} \mathrm{BO}_{3}\end{array}$ & $+\mathrm{NaOMe}$ & $\begin{array}{c}R_{f} \text { values } \\
\text { in } B A W \\
(4: 1: 2)\end{array}$ \\
\hline \multirow[t]{2}{*}{$\mathbf{F 1}$} & I & $\begin{array}{l}365 \\
320\end{array}$ & $\begin{array}{l}420 \\
350 \\
302\end{array}$ & $\begin{array}{l}420 \\
347 \\
302 \\
\end{array}$ & $\begin{array}{l}385 \\
\mathbf{3 0 2}\end{array}$ & $\begin{array}{l}371 \\
318\end{array}$ & $\begin{array}{c}415 \\
316 \\
\vdots \\
\end{array}$ & \multirow[t]{2}{*}{0.79} \\
\hline & II & 265 & 267 & 268 & 271 & 264 & 277 & \\
\hline \multirow[t]{2}{*}{ F2 } & I & $\begin{array}{l}377 \\
325\end{array}$ & $\begin{array}{l}430 \\
355 \\
310\end{array}$ & $\begin{array}{l}429 \\
356 \\
308 \\
\end{array}$ & $\begin{array}{l}400 \\
340 \\
318 \\
\end{array}$ & $\begin{array}{l}380 \\
320 \\
308 \\
\end{array}$ & $425 \mathrm{dec}$ & \multirow[t]{2}{*}{0.78} \\
\hline & II & 255 & 275 & 273 & 280 & 274 & 288 & \\
\hline \multirow[t]{2}{*}{ F3 } & I & $\begin{array}{l}370 \\
305\end{array}$ & $\begin{array}{l}430 \\
358 \\
300\end{array}$ & $\begin{array}{l}427 \\
355 \\
270\end{array}$ & $\begin{array}{c}390 \text { (dec.) } \\
318\end{array}$ & $\begin{array}{l}375 \\
325 \\
305\end{array}$ & $\begin{array}{c}435 \\
\text { (dec.) } \\
320\end{array}$ & \multirow[t]{2}{*}{0.68} \\
\hline & II & 251 & 262 & 260 & 272 & 253 & 270 & \\
\hline \multirow[t]{2}{*}{ F4 } & $\mathbf{I}$ & 370 & $\begin{array}{l}438 \\
363 \\
303 \\
\end{array}$ & $\begin{array}{l}491 \\
360 \\
304 \\
\end{array}$ & $\begin{array}{l}395 \\
327\end{array}$ & $\begin{array}{l}392 \\
327\end{array}$ & $\begin{array}{c}410 \\
\text { (dec.) }\end{array}$ & \multirow[t]{2}{*}{0.58} \\
\hline & II & $\begin{array}{l}256 \\
269\end{array}$ & 272 & 266 & 273 & 260 & 252 & \\
\hline
\end{tabular}

triterpenes unsubstituted in C, D and $\mathrm{E}$ rings (Fig. 1) and having a hydroxyl group at the lower part of skeleton. ${ }^{11}$ 'H-NMR showed two olefenic protons at $\delta 4.56$ and $\delta 4.68$ (each $1 \mathrm{H}$, brs) and a downfield olefenic methyl groups at $\delta 1.68$ for either taraxasten or lupene skeleton. The ${ }^{13} \mathrm{C}-\mathrm{NMR}$ showed its identify to lupeol rather than taraxasterol (Table 1). This was confirmed by comparing the ${ }^{13} \mathrm{C}-\mathrm{NMR}$ data with that of lupeal..$^{12}$.

Compound 2: The mass spectra of this compound exhibited a molecular ion $\left[\mathrm{M}^{+}\right]$at $\mathrm{m} / \mathrm{z} 468$ and gave fragmentation pattern similar to that of compound 1 . However, the fragment ion peak at $\mathrm{m} / \mathrm{z} 207$ in 1 shifted to $\mathrm{m} / \mathrm{z} 249$ in 2 indicating additional acetate group $\left(\mathrm{CH}_{3} \mathrm{CO}\right)$ to the compound $\mathrm{I}$ which was confirmed by the ${ }^{13} \mathrm{C}-\mathrm{NMR}$ peaks at $\delta 173.6$ and $\delta 21.3$ and downfield shift of $\mathrm{H}_{3}$ in 1 from $\delta 3.19$ (1H, dd, $\mathrm{J}=9.4,4.2 \mathrm{~Hz})$ to $\delta 4.5(1 \mathrm{H}, \mathrm{dd}, \mathrm{J}=8.4,4.8$ $\mathrm{Hz}$ ) in 2, all of these data as well as the comparison of ${ }^{13} \mathrm{C}-\mathrm{NMR}$ with that of lupeol acetate, ${ }^{12}$ (Table 1). Suggested that compound 2 was lupeol acetate.

Compound 3: showed in ${ }^{13} \mathrm{C}-\mathrm{NMR}$, besides a lupene skeleton, a cluster of methylene peaks at $\delta$ 29.2-30, a methyl group at $\delta$ 14.3, a methylene group at 32.1 and a carbonyl peak at $\delta 174.6 \mathrm{ppm}$ indicating possible presence of a fatty acid ester of lupeol. The EIMS showed a very weak peak at $\mathrm{m} / \mathrm{z} 664$ followed by a peak at $\mathrm{m} / \mathrm{z} 649(\mathrm{M}-15)$ followed by successive loss of 14 mass unit. From the above data the compound was identified as lupeol palmitate which has not been previously isolated from the genus Fagonia. 


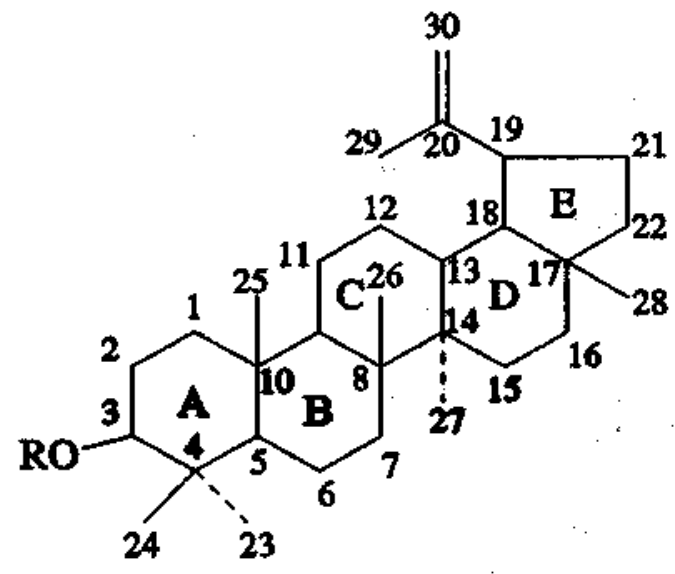

Fig. 1

1: $R=A c$;

3: $\mathrm{R}=$ Pal. $\mathrm{O}=\mathrm{C}-\left(\mathrm{CH}_{2}\right)_{14} \mathrm{CH}_{3} ; \quad$ 4: unidentified<smiles>[R2]c1cc(-c2oc3c([R1])c(O)cc(O)c3c(=O)c2O)ccc1O</smiles>

Fig. 2

$\begin{array}{lll} & \mathrm{R}_{1} & \mathrm{R}_{2} \\ \text { Compound F1 } & \mathrm{H} & \mathrm{H} \\ \text { Compound F2 } & \mathrm{OCH}_{3} & \mathrm{H} \\ \text { Compound F3 } & \mathrm{H} & \mathrm{OCH} \\ \text { Compound F4 } & \mathrm{H} & \mathrm{OH}\end{array}$

Compound 4: gave similar ${ }^{1} \mathrm{H}-\mathrm{NMR}$ and ${ }^{13} \mathrm{C}$ NMR to lupeol acetate. However, its ' $H$ and ${ }^{13} \mathrm{C}$-NMR showed a peak at $\delta 9.0$ and at $\delta 200$, respectively corresponding to the presence of an aldehydic function in compound 4. This was confirmed by MS which showed $\mathrm{M}^{+}$at $\mathrm{m} / \mathrm{z} 482$ and RDA fragmentation at $\mathrm{m} / \mathrm{z} 263$ and $\mathrm{m} / \mathrm{z} 218$ indicating the presence of aldehydic and acetate groups in A/B rings of this lupene derivative. This group may be located probably on $\mathrm{C}_{24}$ due to its chemical shift $\left(\mathrm{C}_{24}\right.$ aldehydic group) appears more downfield. However, due to lack of more information, the structure of this compound is still uncertain.

Compounds F1 and F4 (Fig. 2): were identified as kampferol and querctin respectively, by studing their physical, chemical and UV spectral data with different ionizing and complexing agents. ${ }^{1-15}$ (Table 3) as well as ${ }^{1} \mathbf{H}-\mathrm{NMR}$ spectra (Table 2).

Compound F2 (Fig. 2): was obtained as a yellow amorphous powder, m.p. $269-271^{\circ} \mathrm{C}$. The mass spectrum of $F 2$ exhibited a molecular ion at $\mathrm{m} / \mathrm{z} 316$ in accordance with a flavanol containing four hydroxyls and one methoxyl group. The bathochromic shift $(+48 \mathrm{~nm})$ of band $I$ in $\mathrm{NaOMe}$ relative to band $I$ in $\mathrm{MeOH}$ with increase in intensity indicated the presence of a hydroxyl group at $\mathrm{C}-4$. The presence of $\mathrm{OH}$ at C-7 was indicated by bathochromic shift $(+25$ $\mathrm{nm}$ ) of band II in NaOAc relative to band II in methanol. ${ }^{16}$ The absence of orthodihydroxyl group in ring $B$ indicated by the bathochromic shift in band $\mathrm{I}(+3)$ in $\mathrm{NaOAc} / \mathrm{H}_{3} \mathrm{BO}_{3}$ relative to band $I$ in methanol. The presence of a hydroxyl group at C-5 was evident since the compound appears as a purple spot on paper chromatogram when viewed in UV light. According to the above data compound F2 was deduced as herbacetin-8-methyl ether.

Compound F3 (Fig. 2): was obtained as a yellow amorphous powder, m.p. 308-310. The ${ }^{1} \mathrm{H}-\mathrm{NMR}$ spectrum (DMSO-d ${ }_{6}$ ) confirmed the presence of one methoxyl group ( $\delta 3.62$ ) in addition, NMR signals (Table 2) were observed for five aromatic protons in accordance with isorhamnetin type flavanol $(\delta 7.6,7.5$ and 6.95 for B-ring and 6.4 and 6.2 for the A-ring protons). The presence of a hydroxyl group at C-5 was evident since the compound appeared as a purple spot on the paper chromatogram when viewed in UV light. The presence of a second hydroxyl group at C-7 was indicated by a bathochromic shift $(+21 \mathrm{~nm})$ of band II in $\mathrm{NaOAc}$, relative to band II in methanol..$^{16}$ The bathochromic shift in band $\mathrm{I}(+5 \mathrm{~nm})$ and $(+2$ $\mathrm{nm}$ ) band II with $\mathrm{NaOAc} / \mathrm{H}_{3} \mathrm{BO}_{3}$ indicating the absence of a free orthodihydroxyl group in ring B. So compound F3 was identified as isorhamnetin. 


\section{REFERENCES}

1- V. Tackholm, "Students Flora of Egypt", 2nd Ed. Cario University, 505 (1976).

2- R. N. Chopra, K. L. Handa and I. C. Chopra, Indigenous Drugs of India, p. 507, U.N. Dhur \& Sons, Calcutta (1958).

3- R. N. Chopra, S. L. Nayar and I. C. Chopra, Glossary of Indian Medicinal Plants, p. 116. Council of Scientific \& Industrial Research, New Delhi (1956).

4- F. R. Melek, T. Miyase, D. O. El-Gindi, S. M. Abdel-Khalik and M. Y. Haggag, Phytochemistry, 42, 5, 1405 (1996).

5- S. A. Al-Wakeel, Biochem. Syst. Ecol., 20, 259 (1992).

6- S. 1. El-Negoumy, S. A. Al-Wakeel and M. N. El-Hadidi, Phytochemistry, 25, 2423 (1987).

7- L. A. Refaey, Ph.D. Thesis; Faculty of Science, Ain-Shams University (1992).

8- M. R. El-Gindi, Ph.D. Thesis, Faculty of Pharmacy, Cairo University (1995).

9- Z. F. Ahmed, M. Rizk, F. M. Hammoda and M. M. Abdel Gawad, J. Pharm. Sci., U.A.R., 10, 103 (1969).
10- A. A. Ansari, L. Kennel and H. Rahamans, Phytochemistry, 26, 1478 (1987).

11- H. Budzikjewicz, J. M. Willson and C. Djerassi, Structure elucidation of natural products by mass spectrometry, San Francisco, London, Amesterdam (1964).

12- M. Sholichin, K. Yamasaki, R. Kasai and O. Tonaka, Chem. Pharm. Bull. 28 (3), $1006(1980)$.

13- T. A. Geissman, Chemistry of flavonoid compounds, the McMillan Company, New York, 7, 72 (1962).

14- E. J. Bryant, J. Am. Chem. Soc., 39, 481 (1950).

15- V. I. Lilvinenko and N. P. Maxyotina, Chemistry of natural products, Russian, 420 (1965).

16- T. J. Mabry, K. R. Markham and M. B. Thomas, The systematic identification of flavonoids, Springer Verlag, New York, Berlin (1970). 